\title{
Renegotiating the European Union's free movement and social security coordination policies: Britain's approaches and interests
}

\author{
THOMAS MILTON
}

tommilton@icloud.com

\begin{abstract}
The EU's freedom of movement has increasingly been brought into question in the last few years as member states have restricted social benefits for EU migrants. Britain proposed in-work benefit restrictions for economically active EU migrants in intergovernmental negotiations leading up to the referendum on its membership to the EU. Access to social benefits is an important component of free movement. It provides EU citizens with social rights in host member states, which promotes internal migration. Restricting free movement threatens European integration because it is a fundamental EU treaty right. This article analyses Britain's preferences towards the EU's free movement and social security coordination policies leading up to the Brexit referendum. Britain's identity, and conceptions of statehood and European integration were the main determinants of state action. Britain's desire to restrict these policies significantly influenced its decision to leave the EU, which fundamentally changed the trajectory of European integration.
\end{abstract}

Key words: Britain, Freedom of Movement, Social Security

\section{Introduction}

The free movement of people throughout the European Union (EU) has increasingly been brought into question in the last few years as some member states have restricted, or attempted to restrict, EU migrants' right to access social benefits. The most pertinent example of this was Britain's desire to reshape the EU's free movement and social security coordination policies, leading up to the referendum on its membership of the EU, so that it conformed with Britain's interests. In a letter to Donald Tusk, the President of the Council of Ministers, Prime Minister David Cameron proposed restrictions to EU migrants' right to access in-work benefits until they had resided and worked in Britain for four years (Cameron, 2015a, 5). The proposal was widely criticised by the EU and other member states on the grounds that it undermined the principle of free movement because social rights provide EU migrants with protections in host member states, which promotes free movement (Leonard, 2015, 1-2; Ruparel, Booth, Scarpetta, 2015, 5, 7-11). In the lead-up to the Brexit referendum, this issue was a litmus test for the future of British-European relations and the trajectory of the EU, as Cameron stated that he would only support Britain remaining in the EU if his proposal was implemented through EU reform. Further, Britain's desire to restrict these policies significantly influenced its decision to leave the EU, which fundamentally changed the trajectory of European integration. 
If implemented, Cameron's policy would not have overtly violated the principle of free movement - affirmed through the Treaty of the Functioning of the European Union (TFEU) and the European Parliament and Council of the European Union's Directive 2004/38/EC - because it did not restrict their rights to enter and reside in Britain. However, it would have violated the principle of non-discrimination, which is affirmed in the aforementioned European legislation and the EU's social security coordination policies, the European Parliament and Council's Regulations 883/2004 and 987/2009. Therefore, the EU's free movement and social security coordination policies do not allow for member states to restrict benefits for economically active EU migrants. Cameron's proposal would be discriminatory because economically active EU migrants would have inferior employment and social rights compared with British citizens in the same job. Moreover, EU citizens would also have to contribute to Britain's welfare system for four years before they gained the right to access it. Therefore, Cameron's proposal would have affected freedom of movement because the principle of nondiscrimination and the EU's social security coordination policies encourage internal migration, and ensure that it functions as intended.

Due to the shape of European integration, it was necessary for Cameron to pursue this proposal through intergovernmental negotiations, rather than solely through domestic implementation. The ECJ would likely have overturned the policy if it was implemented without an agreement being reached at the European level (Cusick, 2016, 1). Cameron included the proposal in his broader EU reform agenda, which was particularly important because it appeared likely that member states would support the rest of his reform agenda due to the moderate nature of Cameron's other proposals.

This article analyses Britain's approaches and interests to the EU's free movement and social security coordination policies, until January 2016 when Prime Minister David Cameron toured the continent to garner support for this proposal amongst the EU and member states. Britain's identity and preferred conceptions of statehood and European integration were the most important determinants of the Cameron premiership's desire to restrict the EU's free movement and social security coordination policies. Britain primarily views the EU as an economic integration project, which advances its economic interests, and opposes integration that it perceives to undermine British sovereignty. Cameron's assertive and eurosceptic approach to British-EU relations was also influenced by Britain's European and domestic social, economic and political preferences.

\section{Britain's European Interests}

\section{Sovereignty}

Cameron's proposal to restrict in-work benefits for EU migrants fundamentally sought to weaken Britain's obligations to the EU's free movement and social security coordination policies, in order to redirect sovereignty from the European to the nationstate level of governance. He believed that London should have the authority to determine Britain's policies in these areas, so that it could control EU migrants' entry, residence and welfare eligibility in a way that ensured these policies conformed with Britain's domestic preferences (Cameron, 2014, 1; Cameron, 2015a, 4-5; Cameron, 2015b, 7-8). This perspective demonstrated Cameron's increasingly assertive and eurosceptic approach to British-EU relations. It also reflected the notion that the British government should be held to account by the British parliament and public, 
rather than European level political actors because these are politically salient policy areas, especially due to the perception that benefit tourism was prevalent amongst EU migrants in Britain (Costello \& Hancox, 2014, 4; Seeleib-Kaiser, 2015, 1). This perspective was particularly pertinent because a state's immigration and social welfare policies are overtly linked to its sovereignty as they affect the bargain between state and society, which is a fundamental component of a state's identity. Hence, Cameron's proposal was strongly influenced by Britain's underlying conception of statehood, in which it valued its independence and sovereignty. These values were often prioritised over London's obligations to the EU because it had not adopted a Europeanised identity, ${ }^{1}$ and the perception that Britain could succeed outside of the EU remained prevalent. Therefore, Britain's support for the EU was contingent on the perception that its membership promoted Britain's economic interests, because London primarily conceived of the EU as an economic integration project, which did not supersede the nation-state or undermine its sovereignty; although economic integration still has implications on a state's sovereignty insofar as economic integration alters the state's ability to formulate economic policy. In comparison, a number of other member-states considered the EU to be a political integration project, which involved, to an extent, the transfer of sovereignty to the EU. Notably, Cameron's broader EU reform agenda primarily focused on redirecting sovereignty and ensuring that the EU advanced Britain's national and economic interests (Cameron, 2015b, 8-10). Accordingly, inwork benefit restrictions were prominent in Cameron's public discourse, in an attempt to justify and gain public support for his EU reform agenda, because immigration and social welfare policies are politically salient issues, which resonate amongst the public. In contrast Cameron's proposals on economic governance and competitiveness were technocratic and largely removed from his public discourse. Cameron's proposals to restrict in-work benefits for recent EU migrants reflected his Government's desire to implement policies that conformed with Britain's perceived contemporary preferences.

\section{Influence in Shaping European Integration}

Cameron's desire to reduce Britain's obligations to the EU's free movement and social security coordination policies were also influenced by London's negligible influence in shaping these policies through successive EU treaty reform. Britain, under the Thatcher premiership, significantly influenced the initial shape of the single market and, by extension, freedom of movement through the Single European Act 1986. The Thatcher Government ensured that the single market was established on the basis of market integration and liberalisation, which conformed with Britain's liberal market economy that lacked state intervention. Due to Britain's euroscepticism, the Thatcher Government sought to reduce the extent of political integration within the single market. Accordingly, it was more hesitant to liberalise the free movement of people and sought to limit this right to the free movement of labour because it did not want to cede significant control of Britain's immigration control policies to Europe, as that would diminish British sovereignty (Allen, 111; Moravcsik, 1991, 28,31-32; Moravcsik, 1998, 314-379). However, Britain had a negligible influence over subsequent treaty reforms that extended the principle of free movement that reduced barriers to internal migration by providing EU migrants with social rights in host member states. The Conservative Government, under the premierships of Thatcher and her successor,

\footnotetext{
${ }^{1}$ Radaelli (2003, p. 30) defines Europeanization as "processes of (a) construction, (b) diffusion and, (c) institutionalization of formal rules, procedures, policy paradigms, styles, 'ways of doing things' and shared beliefs and norms which are first defined and consolidated in the making of EU decisions and then incorporated in the logic of domestic discourse, identities, political structures and public policies.”
} 
Major, opposed the integration of social policy at the European level because of the belief that integrating social policy at the European level would result in the European Economic Community adopting interventionist and protectionist policies that would undermine Britain's neoliberal reforms by bringing, "socialism [...] through the back door" (Thatcher, 1988, 23). Furthermore, it was believed that the integration of social policy would jeopardise Britain's economic efficiency and competitiveness because it would undermine the laissez-faire nature of Britain's economy. Consequently, Britain, influenced by the notion that social policy integration was incongruent with Britain's preferences, opted-out of the EU's social policy when it was integrated through the Maastricht Treaty in 1992. This ensured that London retained control over Britain's social policy, but it meant that it did not get the opportunity to shape the EU's policies (Allen, 2013, 112; Dinan, 2014, 320). Although the succeeding Labour Government under Tony Blair's premiership opted-in to the EU's social policy, it was unable to upload its domestic preferences through the intergovernmental negotiations, which produced the Amsterdam Treaty because its social policy provisions remained consistent with those affirmed in the Maastricht Treaty (Liddle, 2014, 40,276-277; Wall, 2008, 121-127). Therefore, Cameron perceived that Britain had a negligible influence over the development of the EU's social security policies, which affected the utility of free movement, and sought to reshape Britain's obligations to the EU's policies so that it conformed to Britain's preferences.

\section{Single Market}

The shape of Cameron's proposal was also influenced by his desire to maintain Britain's access to the single market. He proposed in-work benefit restrictions because he believed that it effectively balanced his competing interests of regaining control of Britain's immigration and social welfare policies whilst maintaining access to the single market. If Cameron had proposed a policy that overtly undermined the principle of free movement, such as a quota system, which he initially preferred (Graham, 2014, 1), it would have likely resulted in the EU restricting Britain's access to the single market because free movement is a fundamental component of market integration (Crisp, $2016,1)$. Even if Britain withdrew from the EU, it would not be able to access the single market if it did not adhere to the principle of free movement. The Cameron Government sought to maintain access to the single market because it was the aspect of European integration that it valued the most; London significantly shaped the single market, which meant that it conformed with Britain's preferred conception of the EU and it advanced Britain's economic interests. Furthermore, the perception that the single market was economically beneficial was prevalent amongst the British public, and business and political elites (Home Office, 2014, 25-52). Although it is difficult to precisely quantify the extent to which the single market advanced Britain's economic interests, Ilzkovitz et al $(2007,56)$, and Boltho and Eichengreen $(2008,1)$ estimate that the single market raised EU's GDP by $2.2 \%$ and $5 \%$, respectively. Although these studies do not specifically analyse the extent to which Britain benefited from access to the single market, it can be assumed that it raised Britain's GDP because it facilitated greater economic liberalisation and labour market flexibility, which stimulated economic growth (Portes, 2015a, 1). Furthermore, estimates before the referendum suggested that losing access to the single market would reduce Britain's GDP by between 1.1 and 3.1\% (Dhingra, Ottaviano \& Sampson, 2015, 7). British businesses also valued the single market because it provided them with access to other member states' markets and a source of unlimited cheap labour, particularly from A8 and A2 member states, which was conducive to business growth. However, not all British businesses 
benefitted from the single market because businesses who did not export their outputs had to conform to the EU's costly regulatory standards. It was necessary for Cameron's proposal to reflect Britain's business interests because they are an important source of support for the Conservatives. Furthermore, the public valued access to the single market because it provided consumers with more product choices and lower prices due to increased competition within the market. British citizens also valued the right to reside and work in other member states (Cameron, 2015b, 4-7; Department for Business, Innovation and Skills, 2014, 35-50; Home Office, 2014, 25-52). Therefore, Cameron proposed in-work benefits restrictions because he perceived that it effectively balanced his competing preferences of reshaping the EU's free movement and social security coordination policies so that they advanced Britain's perceived interests, while retaining the benefits that access to the single market provided Britain.

\section{Britain's Domestic Preferences}

\section{Social Factors}

Cameron sought to restrict EU migrants' access to in-work benefits to reduce Britain's high positive net-migration rate by reducing the pull factors, which made Britain an attractive destination state for EU migrants. The Conservative Government sought to reduce Britain's total net-migration rate, because they perceived that Britain's consistently high rates of net-migration were economically and socially unsustainable (Conservative Party, 2010, 21; Conservative Party, 2015, 29-31; Robinson, 2013, 7374). Britain's experience with A8 immigration exacerbated Britain's contemporary anti-EU immigrant sentiment because it perceived that A8 migration negatively affected Britain's economy, overburdened its public services, including the welfare system, and exacerbated social tension. Furthermore, the notion that Britain already had an expanding population exacerbated Britain's perception that consistently high levels of net-migration were unsustainable, because they believed that it would overburden Britain's public services and labour market. Although the Cameron Government had the authority to overtly restrict third country immigration, and had implemented highly restrictive immigration control barriers (Cameron, 2014, 1; Conservative Party, 2015, 29-31), it could not overtly restrict EU migrants' right to enter and reside in Britain without violating the principle of free movement. Due to the contemporary shape of the EU's free movement policies, if Britain overtly restricted EU immigration, it would be overturned by the ECJ and the EU would likely restrict Britain's access to the single market (Crisp, 2016, 1; Graham, 2014, 1). Hence, Cameron perceived that restricting EU migrants' access to social benefits in Britain was the best mechanism that could be utilised to reduce the high levels of EU immigration to Britain without overtly undermining the principle of free movement. This is because he believed that Britain's comparatively generous and accessible benefit entitlements, including for those in employment, were a significant pull factor, which encouraged EU immigration to Britain, particularly from A8 and A2 member states (Cameron, 2014, 1; Cameron, 2015b, 7-8). Furthermore, the public supported restricting immigration from the EU; only $59 \%$ and $53 \%$ of Britons supported EU migrants' right to work and live in the EU-28, respectively, which were the second lowest and the lowest levels of support amongst member states (European Commission, 2015, 45-46). However, this perception was somewhat tenuous as employment opportunities and favourable income differentials, including Britain's comparatively generous minimum wage, were more significant pull factors for EU migrants than being able to access Britain's welfare assistance (Benton \& Petrovic, 2013, 12-13). Hence, Cameron's 
approach sought to exploit the public's negative perceptions towards EU migrants to justify restrictions that sought to reduce EU immigration to Britain without overtly undermining the principle of free movement.

\section{Economic Factors}

Cameron's proposal to restrict in-work benefits for recent EU migrants was also influenced by his desire to reduce the prevalence of EU migrants who received social benefits in Britain. Like Cameron's restrictions to the Jobseeker's Allowance (JSA) and Universal Credit for economically inactive EU migrants, this preference was based on the belief that EU migrants, irrespective of their economic status, should not be allowed to receive public benefits until they had contributed to Britain's economy. This was exacerbated by the belief that Britain lacked the authority to significantly control its welfare policies towards EU migrants in the UK, which may be symptomatic of a broader fear European integration would pervade other policy areas, which were typically the purview of domestic policy makers. Hence, Cameron believed that it was necessary to reshape the EU's social security regulations so that they accounted for variations in member states' social security systems so that it conformed to a member states' contemporary interests. Specifically, Cameron sought to provide Britain with the safeguards against benefit tourism that were embedded into conservative welfare systems of continental Europe. Furthermore, Cameron sought to reshape the EU's free movement and social security coordination policies so that they conformed with his preferred conception of these policies; he believed that member states should have the authority to control free movement and welfare benefits because they were not "unqualified right[s]" that citizens of EU member states automatically received (Cameron, 2015b, 7), and that the EU's policies should promote the "the right to work, not to claim" regardless of their economic activity (Cameron in Hewitt, 2015, 1). Cameron believed that it was necessary to restrict EU migrants' access to in-work benefits because they overburdened Britain's economy, which was exacerbated by the trend of significant consistent rates of high positive net-migration from the EU-28. He asserted that approximately $40 \%$ of recent EU migrants to the UK received some form of British welfare assistance, and that over 400,000 EU migrants received in-work benefits, at an average rate of $£ 6,000$ per person, per annum (Cameron, 2014, 1; Cameron, 2015b, 8). Based on Cameron's assertions, Britain spends approximately $£ 2.4 \mathrm{~b}$ on in-work benefits for EU migrants, per annum. However, these claims are tenuous because Cameron refused to announce the exact cost of EU migrants in-work benefit receipt (Dathan, 2016a, 1; Nardelli, 2016, 1). Furthermore, Britain spent $£ 814 \mathrm{~m}$ on Department of Work and Pensions in-work expenditure for EU migrants in the 2013/14 financial year, which comprised 16\% of Britain's in-work expenditure (Department for Work and Pensions, 2016, 5). Moreover, EU migrants do not overburden Britain's economy because they make a net fiscal contribution to the government's budget; it totalled around $+£ 20$ billion between 2001 and 2011, including around $+£ 5$ billion by A10 migrants, which was significant because they were perceived to the most burdensome of EU migrants (Dustmann \& Frattini, 2014, 595). Therefore, Cameron's proposal was primarily influenced by the perceptions amongst parts of the general public that EU migrants overburdened Britain's economy by exploiting its welfare system.

Cameron's proposal, which sought to reduce immigration from the EU, was also influenced by the perception that EU migrants had a negative impact on Britain's labour market. Accordingly, he sought to reshape the EU's contemporary free 
movement policies to increase the extent to which they advanced Britain's interests, from his perspective. Cameron claimed that the influx of immigrant workers, including from the EU-28, negatively affected Britain's labour market because it increased unemployment and decreased wages amongst British workers due to the increased competition for jobs (Cameron, 2015c, 1). This perception was prevalent amongst cleavages of the British public and political elite (Natcen Social Research, 2014, 84-93; Portes, 2015b, 1). It was perceived that they lowered wages because they tended to gain employment in low-skilled jobs, even if they were overqualified for these positions and were willing to work for lower wages than British workers, which overcrowded the lower end of Britain's labour market (Home Office, 2014, 31-37; House of Lords, 2008, 28; Fic, Holland, \& Paluchowski, 2011, 46). This perception was particularly prevalent towards A8 citizens due to the influx of migrants from these member states after 2004. There was strong anecdotal evidence that EU migrants increased unemployment amongst British workers, particularly amongst low-skilled workers. The notion that migrant workers gained employment in 90\% of newly created jobs, between 1997 and 2010, exacerbated this perspective (Cameron, 2015c, 1). Statistical analyses produced different results about the actual effect that EU migrants had on unemployment and wages. Most studies estimated that there was insufficient evidence to conclude that EU migrants significantly affected the British labour market (House of Lords, 2008, 5861; Migration Advisory Committee [MAC], 2010, 7; Migration Watch, 2012, 1; Portes, 2015b, 1). However, it appears that free movement had an uneven impact on different sectors of the British labour market and it exacerbated socio-economic disparities amongst British workers based on the workers' skill level. Regardless, the negative labour market effects were less significant in reality than they were feared to be, although these negative perceptions remained prevalent, presumably based on a given individual's fears that EU immigration may have negative effects on their position within the labour market. Therefore, Cameron's desire to reduce the pull factors of EU migration to Britain by restricting in-work benefits reflected the prevalent perception that EU migrants negatively affected Britain's labour market.

\section{Political Factors}

Cameron's proposal was influenced by his belief that he needed to balance the Conservatives' internal party preferences with that of European level actors. He sought an agreement that would protect his standing within the Conservative Party, whilst ensuring that Britain remained in a reformed EU that advanced the UK's European interests and domestic preferences. The framing of his proposed in-work benefit restrictions was particularly important because it was viewed as a litmus test for Britain's future relationship with the EU. On the one hand, it was necessary for Cameron to pander to the Conservative Party's powerful eurosceptic faction - who sought to regain meaningful control of Britain's immigration and social security policies - to protect his position within the party. Cameron risked losing the support of his party if he did not announce proposals which conformed with these preferences because two-thirds of Conservative MPs were willing to vote in favour of Britain leaving the EU (Helm \& McDonald, 2016, 1), including half of Cabinet and his faction of the party (Dathan, 2016b, 1; Rose, 2015, 1). On the other hand, it was necessary for Cameron to announce a relatively moderate proposal, which did not overtly undermine the principle of free movement because he needed to gain support from the EU and other member states, who sought to uphold this principle, for his proposal to be implemented (Leonard, 2015, 1-2; Ruparel, Booth \& Scarpetta, 2015, 5,7-11). This was particularly important because Cameron had publicly stated that he sought for Britain 
to remain in the EU, as he believed that a reformed EU would advance Britain's interests. However, Cameron had previously stated that he would only support Britain remaining in the EU if his EU reform agenda was supported in intergovernmental negotiations (Cameron, 2013, 1; Cameron, 2015b, 6-7), in which his in-work benefit restriction proposal was a bellwether for Cameron's success. Cameron's support for remaining in the EU was considered important because it maximised the probability of this occurring; his support for the 'in' campaign was estimated to swing public opinion by $2.8 \%$ in favour of this option, which could prove decisive in what appears to be a close referendum (Menon, 2015, 1). Furthermore, as Cameron signaled his preference for Britain to remain in the EU, a Brexit would likely damage his position within the Conservative Party because it would be viewed as a diplomatic failure, which would foster doubts about his leadership, in spite of whether he ultimately supports the 'in' or 'out' campaign (Rose, 2015, 1). Although Cameron's proposal did not satisfy some Conservative MPs, or European level actors, he believed that this proposal was the most effective way to balance their competing interests to achieve support from both groups.

Cameron's decision to propose in-work benefit restrictions to recent EU migrants reflected his belief that it was necessary to limit the electoral threat that UKIP posed to the Conservative Government in the lead up to the 2015 election. This pressured Cameron to adopt a more assertive and eurosceptic approach to British-EU relations, which influenced Cameron's decision to renegotiate the terms of, and announce a referendum on, Britain's membership of the EU. Before the rise of UKIP, the Conservative Party, under Cameron's leadership, had utilised a "best not mentioned" approach to European issues because they believed it precluded the party gaining the widespread public support which was required to form government (Bale, 2006, 388). Furthermore, Cameron sought to avoid the intra-party divisions resulting from past Conservative Government's European policies, which contributed to the downfall of the Thatcher and Major premierships. However, this approach became untenable after the rise in UKIP support in the 2013 local and by-elections (Gifford, 2014, 512-513; Gruber \& Bale, 2014, .250-251), because they increased the political salience of European issues and euroscepticism amongst the public and political elite. The Cameron Government responded to this threat by adopting a soft eurosceptic approach and increasingly recognised the issues in British-EU relations. Notably, Cameron announced the in-work benefit restriction proposal in the Conservative Party's 2015 election manifesto, and this policy conformed to UKIP's eurosceptic and antiimmigration policies. It sought to demonstrate to the public that the Conservatives were using an assertive approach in their relations with the EU, and that they considered reclaiming control of immigration and social welfare policies to be important. However, the policy was still relatively moderate, which sought to ensure that it did not diminish widespread public support for the Conservatives. This policy sought to alleviate the electoral threat that UKIP posed to the Conservatives in the 2015 election, by reducing the number of traditional Conservative voters, from the important eurosceptic right voter cleavages, who voted for UKIP. The Conservatives considered this necessary because they feared that UKIP would prevent them from gaining the support required to gain a parliamentary majority (Lynch, 2015, 196; Lynch \& Whitaker, 2013, 308). Furthermore, this approach sought to maximise the probability of the Conservatives forming government if it failed to gain a parliamentary majority because it demonstrated that the Conservatives would be willing to make policy concessions to UKIP in exchange for their support of a Conservative-led Government (Gruber \& Bale, 2014, 241; Lynch, 2015, 193). Accordingly, Cameron's 
decision to announce a referendum and renegotiate the terms of Britain's membership to the EU - including the in-work benefit restrictions proposal which was a litmus test for the future of British-EU relations - sought to reduce the electoral threat that UKIP posed to the Conservatives, without jeopardising its support amongst other important voter cleavages.

\section{Conclusion}

This article seeks to understand Britain's perspectives and preferences towards the EU's free movement and social security coordination policies by analysing the Cameron premiership's proposal to restrict in-work benefits for EU migrants in the lead up to the Brexit referendum. Britain's preferred conceptions of statehood and European integration, and perceived domestic preferences were the most significant determinants of its approaches and interests to the EU's policies. Britain favoured economic integration that advanced its interests and did not undermine its sovereignty. London's preferences also reflected its desire to balance their perceived European interests. Cameron sought to re-direct sovereignty to London so that it could control Britain's immigration and social welfare policies, whilst ensuring that the policy did not overtly undermine free movement, as it would jeopardise British access to the single market. Cameron sought to restrict Britain's obligations to the EU's policies because he believed that they did not advance Britain's national and economic interests, which reflected London's negligible role in shaping the Maastricht and Amsterdam Treaties. Further, Cameron's approach reflected prevalent domestic perceptions towards EU migrants' right to enter, reside, work and access benefits. Cameron sought to reduce EU migration and their access to benefits, and they perceived that EU migrants had broadly negative effects on British society and the economy. Intra- and inter-party bargaining also affected Cameron's approach and preferences.

This is an important case study in European integration because there is an increasing trend of member states restricting or attempting to restrict EU migrants' rights to access social benefits within their jurisdiction. Member states' decisions to restrict or attempt to restrict EU citizens' rights to free movement and social benefits in a host member state has significant implications for the European integration project. These rights are intrinsically linked because the EU's social security coordination regulations provide EU citizens with social rights and protections in a host member state, which promote and incentivise free movement. It also affirms the principle of nondiscrimination irrespective of nationality, which is a core component of free movement. Restricting or undermining the principle of free movement threatens the existence, contemporary shape and future trajectory of the EU because it is a fundamental treaty right and one of the most important achievements of the European integration project. It is also a vital component of the EU as a political and economic project because it promotes market integration and closer connections between member states' citizens and governments. Hence, it is particularly concerning that Cameron attached proposals to restrict social rights to Britain's referendum on its membership to the EU, which was a litmus test on the future of British-EU relations, because it threatened the contemporary shape of the EU, regardless of whether Cameron's proposal was implemented, or the shape that it took. This resulted in a situation where, on the one hand, if Britain remained in the EU, it was likely that Cameron's proposal would be implemented or partially implemented through EU reform, which would undermine the principle of free movement, and by extension the 
EU. On the other hand, Cameron's failure to reform the EU so that it conformed with his proposal - to a degree that was acceptable to the general public - was a significant factor in Britain's decision to vote for Brexit, which has created uncertainty and looks to undermine the contemporary shape of the European integration project. The extensive negotiations that have occurred since Britain voted to withdraw from the EU have underlined the difficulty for the EU and its other member states to reconcile these competing interests in a way that does not affect the contemporary conception and the future trajectory of the EU.

It is likely that comparable issues will continue to persist between the EU and its member states in the future because the contemporary shape of integration is not working effectively. The contemporary shape of these policies attempts to balance member states' interests without really satisfying anyone's interests because they have competing perspectives and domestic preferences towards the EU's free movement and social security coordination policies, which are difficult to reconcile. Therefore, it appears that the contemporary equilibrium of integration in these policy areas needs to be readjusted, by providing member states with greater control of their national immigration and social security policies or by further integrating these policy areas so that member states do not have the ability to restrict EU citizens' free movement or social rights. These issues reflect the way in which member states have largely failed to develop a collective Europeanised identity because they view their citizens differently from European citizens from other member states. Furthermore, member states generally prioritise their domestic preferences when they shape and adapt to the European integration process.

\section{Bibliography}

Allen. D. (2013). The United Kingdom: Towards Isolation and a Parting of Ways?. In S. Bulmer and C. Lequesne (Eds.), The Member States of the European Union (pp. 109-133). Oxford: Oxford University Press.

Bale, T. (2006) Between a Soft and a Hard Place? The Conservative Party, Valence Politics and the Need for a New "Euro-realism." Parliamentary Affairs, 59(3), 385400.

Benton, M., Petrovic, M. (2013). How Free Is Free Movement? Dynamics and Drivers of Mobility within the European Union. Rotterdam: Migration Policy Institute Europe.

Boltho, A., \& Eichengreen, B. (2008). The Economic Impact of European Integration (Discussion Paper No. 6820). London: Centre for Economic Policy Research.

Cameron, D. (2013, January 23). EU Speech presented at Bloomberg. Retrieved from https://www.gov.uk/government/speeches/eu-speech-at-bloomberg.

Cameron, D. (2014, November 28). Prime Minister's Speech presented at JCB Staffordshire. Retrieved from https://www.gov.uk/government/speeches/jcbstaffordshire-prime-ministers-speech.

Cameron, D. (2015a, November 10). A New Settlement for the United Kingdom in a Reformed European Union (Letter to Donald Tusk). Retrieved from 
https://www.gov.uk/government/uploads/system/uploads/attachment_data/file/47 5679/Donald_Tusk_letter.pdf.

Cameron, D. (2015b, November 10). The Future of Britain's Relationship with the EU speech presented at Catham House. Retrieved from

https://www.chathamhouse.org/sites/files/chathamhouse/events/special/20151110

DavidCameron\%20\%28NEW\%29.pdf.

Cameron, D. (2015c, May 21). Prime Minister's Speech on Immigration presented ahead of the Queen's Speech. Retrieved from

https://www.gov.uk/government/speeches/pm-speech-on-immigration.

Conservative Party. (1983). Conservative General Election Manifesto. London: Conservative Party.

Conservative Party. (1983). (1986). Conservative General Election Manifesto.

London: Conservative Party.

Conservative Party. (1983). (2015). Conservative General Election Manifesto.

London: Conservative Party.

Costello, C., Hancox, E. (2014). The UK, EU Citizenship and Free Movement of Persons. The Migration Observatory. Retrieved from http://www.migrationobservatory.ox.ac.uk/sites/files/migobs/UK_EU_Citizenship \%2O_Free_Movement.pdf.

Crisp, J. (2016). House of Lords Warned EU will Punish UK if it Votes for Brexit. EurActiv. Retrieved from http://www.euractiv.com/sections/uk-europe/house-lordswarned-eu-will-punish-uk-if-it-votes-brexit-320944.

Cusick, J. (2016). EU Referendum: David Cameron's Touted EU Deal Could Face Legal Challenge, Experts Warn. The Independent. Retrieved from http://www.independent.co.uk/news/uk/politics/eu-referendum-david-cameron-stouted-eu-deal-could-face-legal-challenge-experts-warn-a6804466.html.

Dathan, M. (2016a). Minister admits David Cameron has no 'factual evidence' to prove 'benefit tourism' causes mass EU migration. The Independent. Retrieved from http://www.independent.co.uk/news/uk/politics/minister-admits-david-cameronhas-no-factual-evidence-to-prove-benefit-tourism-causes-mass-eu-a6802326.html.

Dathan, M. (2016b). EU Referendum: David Cameron Dodges Question over whether he'll resign if he loses EU vote. The Independent. Retrieved from http://www.independent.co.uk/news/uk/politics/eu-referendum-david-camerondodges-question-over-whether-hell-resign-if-he-loses-eu-vote-a6797946.html.

Department for Business, Innovation and Skills. (2014). Review of the Balance of Competences between the United Kingdom and the European Union Single Market: Single Market. Retrieved from https://www.gov.uk/government/uploads/system/uploads/attachment_data/file/22 7069/2901084_SingleMarket_acc.pdf. 
Department for Work and Pensions. (2016). DWP benefit expenditure on EEA national-led claims 2013/14 (Public Expenditure: Statistical Analyses 2016). Westminster: Her Majesty's Stationery Office.

Dhingra, S., Ottaviano, G., Sampson, T. (2015). Should We Stay or Should We Go? The Economic Consequences of Leaving the EU (Report No. EA022). London: London School of Economics and Political Science.

Dinan, D. (2014). A Special Case: The United Kingdom and the European Union. In D. Dinan (Ed.) Origins and Evolution of the European Union (pp. 305-326). Oxford: Oxford University Press.

Dustmann, C., \& Frattini, T. (2014). The Fiscal Effects of Immigration to the UK. The Economic Journal, 124(580), F593-F643.

European Commission. (2015). Standard Eurobarometer 83 - Spring 2015 - Public Opinion in the European Union, Tables of Results. Brussels: European Commission.

Fic, T., Holland, D., \& Paluchowski, P. (2011). Labour Mobility within the EU - The Impact of Enlargement and the Functioning of the Transitional Arrangements (Discussion Paper No. 379). London: National Institute of Economic and Social Research.

Foreign and Commonwealth Office (1984). Europe - The Future. Journal of Common Market Studies, 23(1), 73-81.

Gifford, C. (2014). The People Against Europe: The Eurosceptic Challenge to the United Kingdom's Coalition Government. Journal of Common Market Studies, 52(3), 512-528.

Graham, G. (2014). David Cameron's Plans to Limit Immigration through Quotas for EU workers is Illegal, European President says. The Guardian. Retrieved from http://www.telegraph.co.uk/news/uknews/immigration/11172379/David-Cameronsplans-to-limit-immigration-through-quotas-for-EU-workers-is-illegal-EuropeanPresident-says.html.

Gruber, O., \& Bale, T. (2014). And it's Good Night Vienna. How (Not) to Deal with the Populist Radical Right: The Conservatives, UKIP and some Lessons from the Heartland. British Politics, 9, 237-254.

Helm, T., \& McDonald, H. (2016). Two-Thirds of Tory MPs want Britain to Quit European Union. The Guardian. Retrieved from http://www.theguardian.com/politics/2016/jan/o9/tory-mps-britain-europeanunion-eu-brexit.

Hewitt, G. (2015). David Cameron's complex balancing act on Europe. BBC. Retrieved from http://www.bbc.com/news/uk-politics-35094352.

Home Office. (2014). Review of the Balance of Competences between the United Kingdom and the European Union Single Market: Free Movement of Persons. Retrieved from 
https://www.gov.uk/government/uploads/system/uploads/attachment_data/file/33 5088/SingleMarketFree_MovementPersons.pdf.

House of Lords. (2008). The Economic Impact of Immigration. (Select Committee on Economic Affairs: 1st Report of Session 2007-08). London: The Stationery Office Limited.

Ilzkovitz, F., Dierx, A., Kavocs, V. \& Sousa, N. (2007) Steps Towards a Deeper Economic Integration: The Internal Market in the 21st Century - a Contribution to the Single Market Review (European Economy No. 271). Brussels: European Commission.

Leonard, M. (2015). Britain in Europe Renegotiation Scorecard. European Council on Foreign Relations. Retrieved from http://www.ecfr.eu/europeanpower/britain/renegotiation\#.

Liddle, R. (2014). The Europe Dilemma: Britain and the Drama of EU Integration. New York: I.B. Tauris.

Lynch, P. (2015). Conservative Modernisation and European Integration: From Silence to Salience and Schism. British Politics, 10, 185-203.

Lynch, P. \& Whitaker, R. (2013). Rivalry on the right: The Conservatives, the UK Independence Party (UKIP) and the EU issue. British Politics, 8(3), 285-312.

Menon, A. (2015). Cameron's real test is in Westminster not Brussels. The UK in a Changing Europe. Retrieved from http://ukandeu.ac.uk/camerons-real-test-is-inwestminster-not-brussels/.

Migration Advisory Committee. (2010). Limits on Migration: Limits on Tier 1 and Tier 2 for 2011/12 and supporting policies. London: Home Office.

Migration Watch. (2012). Economic Impacts of Immigration to the UK (Briefing Paper 1.29). Retrieved from http://www.migrationwatchuk.org/pdfs/BP1_29.pdf.

Moravcsik, A. (1991). Negotiating the Single European Act: National Interests and Conventional Statecraft in the European Community. International Organization, 45(1), 19-56.

Moravcsik, A. (1998). The Choice for Europe: Social Purpose and State Power from Messina to Maastricht. Ithaca: Cornell University Press.

Nardelli, A. (2016). Key Data on Migrant Benefit Claimants Being Hidden, Tom Watson says. The Guardian. Retrieved from

http://www.theguardian.com/politics/2016/jan/o8/hmrc-key-data-migrant-benefitclaimants-hidden-tom-watson-labour.

NatCen Social Research. (2014). British Social Attitudes (Report No. 31). London: NatCen Social Research.

Parliament and Council Directive (EC). 2004/38 of 29 April 2004 on the right of citizens of the Union and their family members to move and reside freely within the territory of the Member States amending Regulation (EEC) No 1612/68 and repealing 
Directives 64/221/EEC, 68/360/EEC, 72/194/EEC, 73/148/EEC, 75/34/EEC, 75/35/EEC, 90/364/EEC, 90/365/EEC and 93/96/EEC. (2004). Official Journal of the European Union, L158/ 77.

Parliament and Council Regulation (EC). 883/2004 of 29 April 2004 on the coordination of social security systems. (2004). Official Journal of the European Union, L166/1.

Parliament and Council Regulation (EC). 987/2009 of 16 September 2009 on laying down the procedure for implementing Regulation (EC) No 883/2004 on the coordination of social security systems (2009). Official Journal of the European Union, L284/1.

Portes, J. (2015a). Migrants, Benefits and the UK's Renegotiation. National Institute of Economic and Social Research. Retrieved from http://www.niesr.ac.uk/blog/migrants-benefits-and-uks-renegotiation-questionsand-answers-updated\#.Vrawz-sWXzK.

Portes, J. (2015b). The Benefits of Immigration. The UK in a Changing Europe. Retrieved from http://ukandeu.ac.uk/the-benefits-of-immigration/.

Radaelli, C. M. (2003). The Europeanization of Public Policy. In K. Featherstone \& C.M. Radaelli (Eds.), The Politics of Europeanization (pp.27-56). Oxford: Oxford University Press.

Robinson, D. (2013). Migration policy Under the Coalition Government. People, Place and Policy, 7(2), 73-81.

Rose, R. (2015). Disaster Scenario for Cameron on Europe. The UK in a Changing Europe. Retrieved from http://ukandeu.ac.uk/disaster-scenario-for-cameron-oneurope/.

Ruparel, R., Booth, S., Scarpetta, V. (2015). Where do EU Countries Stand on the UK's EU reform Demands?. Open Europe. Retrieved from

http://openeurope.org.uk/intelligence/britain-and-the-eu/open-europes-eu-reformheat-map-where-do-eu-countries-stand-on-the-uks-eu-reform-demands/.

Seeleib-Kaiser, M. (2015). Freedom of Movement in the EU. The UK in a Changing Europe. Retrieved from http://ukandeu.ac.uk/freedom-of-movement-in-the-eu/.

Thatcher, M. (1988, October 14). Speech to Conservative Party Conference presented at Conference Centre, Brighton

Treaty on the Functioning of the European Union [TFEU], Consolidated Version, 2012. C326/47. Retrieved from http://eur-lex.europa.eu/legalcontent/EN/TXT/PDF/?uri=CELEX:12012E/TXT\&from=EN.

Wall, S. (2008). A Stranger in Europe: Britain and the EU from Thatcher to Blair. Oxford: Oxford University Press.

Young, H. (1999). The Bless Plot, Britain and Europe from Churchill to Blair.

Basingstoke and London: Palgrave MacMillan. 
Milton, ANZJES 1O(2)

Young, J.W. (2000). Britain and European Unity, 1945-1999. London: Palgrave MacMillan. 